This Journal is available in Telkom University online Journals

Jurnal Manajemen Indonesia

\title{
The Effect of Training Results Perception on Individual Work Performance of Employee Moderated by Intrinsic and Extrinsic Motivation
}

\author{
Hidayah Turachma ${ }^{1}$, Hidajat Hendarsjah ${ }^{2}$ \\ ${ }^{1,2}$ Faculty of Economics and Business, Sebelas Maret University, Surakarta, Indonesia
}

\begin{abstract}
This study examines the effect of training result perception on individual work performance included intrinsic and extrinsic motivations as a moderation variable. As quantitative hypothesis-testing research, this study selected 453 samples among of 1.311 population from PT KAI's employees in field operator positions. The data is collected by a close questionnaire with Likert scale 1-5. All instruments were valid and reliable is assessed through Factor and Cronbach's Alpha Analysis. Hypothesis testing is carried out using Hierarchical Regression Analysis by including the multicollinearity test as a prerequisite for analysis. The results show that training result perceptions and extrinsic motivation simultaneously or partially have a positive and significant effect on individual employee performance, but intrinsic motivation have not significant effect. Intrinsic or extrinsic motivation does not moderate or strengthen the relationship between training result perceptions and individual employee performance. The three independent variables are not associated to each other. PT KAI employees, especially those in field operator positions are more oriented towards extrinsic results than intrinsic ones. The implication for PT KAI is that to improve the individual performance of its employees, the organization should be more focus on improving training, external motivation or both. This depends on the vision, long-term goals, and resources of PT KAI.
\end{abstract}

Keywords-Training, Intrinsic Motivation, Extrinsic Motivation, and Individual Work Performance

\begin{abstract}
Abstrak
Penelitian ini menguji pengaruh persepsi hasil pelatihan pada kinerja individual karyawan serta pemoderasian motivasi intrinsik dan ekstrinsik dalam memperkuat pengaruh persepsi hasil pelatihan pada kinerja individual karyawan. Sebagai penelitian kuantitatif, penelitian ini memilih 453 sampel di antara 1.311 populasi karyawan PT KAI pada posisi jabatan pelaksana. Pengumpulan data dilakukan dengan kuesioner tertutup dengan skala likert 1-5. Semua instrumen yang valid dan reliabel dinilai melalui Factor Analysis dan Cronbach's Alpha Analysis. Pengujian hipotesis dilakukan dengan menggunakan Hierarchical Regression Analysis dengan menyertakan uji multikolinieritas sebagai prasyarat analisis. Hasil penelitian menunjukkan bahwa persepsi hasil pelatihan dan motivasi ekstrinsik secara simultan maupun parsial berpengaruh positif dan signifikan terhadap kinerja individual karyawan, namun motivasi intrinsik tidak berpengaruh signifikan. Motivasi intrinsik atau ekstrinsik tidak memoderasi atau memperkuat hubungan antara persepsi hasil pelatihan pada kinerja individual karyawan. Ketiga variabel independen tersebut tidak saling terkait. Karyawan PT KAI, khususnya yang menduduki jabatan pelaksana, lebih berorientasi pada hasil ekstrinsik daripada hasil intrinsik. Implikasinya bagi PT KAI adalah untuk meningkatkan kinerja individu karyawannya, organisasi dapat fokus pada peningkatan pelatihan, motivasi ekstrinsik atau keduanya. Ini tergantung pada visi, tujuan jangka panjang, dan sumber daya PT KAI.
\end{abstract}

Kata kunci-Pelatihan, Motivasi Intrinsik. Motivasi Ekstrinsik, Kinerja Individual

\section{INTRODUCTION}

Work performance is an important factor for the company. Rotundo and Sackett (2002) in Indriasari and Setyorini (2018) mentioned that work performance is a concept as an action and behavior under individual control 
and may be used as a contribution to corporate goals. This is because the improvement of employee performance will have a positive impact on the company's success. That way, the company has to actively pay attention to employees development and need to explore the key factor related to employee performance.

Training and education are one of effort of a company to develop their employees' skill as we know that employees skill are the key factor which determined a work performance. Training and education able to improve the technical, conceptual, and attitude of employees according to job requirements. Education itself relates to the improvement of general knowledge and understanding of the job as a whole, while training is an effort to increase the knowledge and skills of an employee in the specific job position (Priyono and Marnis, 2008)

Effective training and development is an investment in the human resources of an organization, with both immediate and long-range returns. Training is a key element for improved performance; it can increase the level of individual and organizational competency. Training holds the key to unlock the potential growth and development opportunities to achieve a competitive edge. Training programs helps in making acquaintance of employees with more advance technology and attaining robust competencies and skills in order to handle the functions and basics of newly introduced technical equipment. Training facilitates the updating of skills and lead to increase commitment, well-being, and sense of belonging, thus directly strengthening the organization's competitiveness. Training has been an important variable in increasing employee performance (Bhat, 2013)

PT Kereta Api Indonesia (Persero) is a State-Owned Enterprise (SOE) who provides public railway transportation services. Training and education activities in PT KAI were managed by its subsidiaries company name Ir. H. Juanda Education and Training Center. This organization has a vision to train all PT KAI's employees to be more competent and able to work effective and efficiently according to their respective functions in achieving company goals. The trainings provided by the company ideally improve employees' competence that will lead to higher individual performance. Even though had attended many trainings, PT KAI's employees remain have standards performance, the employees who meet the expectation results could be counted on the fingers of one hand. The human resources productivity of PT KAI in 2019 was lower than in 2018 and 2017. Based on the unit of transportation (kilometers), the human resources productivity in 2019 was $103.60 \%$, decreasing from $106.36 \%$ in 2018, and $106.00 \%$ in 2017. Meanwhile, based on the unit of income, human resource productivity in 2019 was 97.72\%, decreasing from 140.37\% in 2018, and 132.31\% in 2017 (Annual Report of PT KAI, 2017-2019). Another phenomenon shows that in general, the performance of PT KAI has also decreased financially. In 2019, the health level of PT KAI recorded a total score of 90.50 with the predicate "AA" or healthy. This number is lower than the score of 93.0 with the title "AA" in 2018 and 93.5 with the title "AA" in 2017.

Training evaluation report of Pusdiklat Ir. H. Djuanda showed that the training participants satisfaction is increase in year to year, from satisfying in 2017 increase to very satisfying in 2018 and 2019. Meanwhile, based on the competency aspect, the competency level of training participants increased from an average of 3.05 in 2017 to 3.18 in 2018 and 3.22 in 2019. It shows that the implementation of training by PT KAI from year to year is better. Training activities continued to increase, however, in general, HR productivity and company performance declined. This inconsistency encourages researcher to examine training and other factors that can be predictors of employees' individual work performance. According to expectancy theory from Vroom (1964), performance depends on motivation, where the motivation itself is determined by the level of expectations or perceptions of the goals which will be achieved. Training can indeed affect an individual work performance, but how big the influence, it absolutely depends on employees' work motivation (Colquit et al., 2019).

Beside training, motivation is a variable that consistently and directly associate to work performance. According to Usmara (2006), motivation is a collection of power, coming from inside and outside of each individual initiating an attitude and determining its shape, direction and intensity. Motivation from inside of employee also determines the results of their individual work performance (Firmandani, 2014). Robbins (2005) argues that performance is a function of ability and motivation. If one is inadequate, it will have a negative effect on performance (Bukit et al., 2017). In this case, work motivation consisting of intrinsic and extrinsic motivation as a predictor of strengthening or weakening the relationship between training and work performance (moderation).

From those description, it can be identified that in an organization, training, motivation, and performance are mutually correlated. Training is a way to increase employees' individual work performance, therefore, training results perception can influence individual work performance in both directly or indirectly depending on the level of training effectiveness and employees motivation itself. Based on this background, researcher interested to examines the effect of training result perception to employees' individual work performance moderated by 
intrinsic and extrinsic motivation. The goals are to examine and analyze the effect of training results perception to employees' individual work performance, as well as to investigate intrinsic and extrinsic motivation as moderation in strengthening that effect.

\section{LITERATURE REVIEW AND HYPOTHESIS DEVELOPMENT}

\section{A. Individual Training and Work Performance of the Employee}

Training can encourage employees to improve their technical skills and work motivation, especially those related to their knowledge and competence (Fletcher et al., 2016). Training is not only to build employees' knowledge and abilities but also as a communication tool between the company and its employees to showed that the company commits and cares for its employees (Wright and Kehoe, 2008). Training will increase the employees' satisfaction and commitment, so could reduce their disappointment regarding the work then eager their motivation to work better (Fletcher et al., 2016). Therefore, the training perception directly correlated to employee involvement in their work (Salanova et al., 2005; Bakker, 2017).

Guan and Frenkel (2018) in their research have proven that training can improve employees performance, especially in the category of task performance and organizational citizenship behavior (OCB), the behavior or initiative of individual to work more than what they are assigned as employees, such as willing to help others' job, offering an assistance, and so on. Training perceptions are positively associated with individual work performance of the employee because training lead to positive work attitudes including job satisfaction (Chiang et al., 2005), self-efficacy (Axtell and Parker, 2003) and organizational commitment (Ahmad and Bakar, 2003).

Asfaw et al. (2015) and Rakhmalina et al. (2017), also proved that training has a positive and significant correlation to employees performance and effectiveness. In his research on PT BPR Sukasada showed that the training able to increase employees work performance due to most of employees believe that all guideline or material are given from the training has to be understood to achieved a maximum work performance. Bhat (2013) stated that training can be a motivational factor for employees to improved their knowledge so they have a high capability to finish their job and able to give better outcomes. In addition, training is also considered useful in keeping up with any changes that occur due to technological innovation, market competition, organizational structure, and most importantly training carry out a key role in improving employees performance. Based on this study, the first hypothesis can be drawn, is:

H1: Training results perceptions have a positive effect to individual work performance of employees

\section{B. Intrinsic Motivation and Individual Work Performance of the Employee}

According to Lin (2011) intrinsic motivation has an effect on individual work performance of the employee (Saeed and Asghar, 2012). Intrinsic motivation can moderate the relationship between training and individual work performance of the employee. Dysvik (2013) in his research involving 114 Nowegia service companies proved that the training participants perception was positively influenced the employees performance only for employees who possessing high intrinsic motivation. The high performance is only shown by the employees who attending training with a high interest and motivation.

Rakhmalina et al. (2017) stated that motivation has a positive and significant effect on employee performance. Motivation has a direct effect on employee competence and indirectly on performance; motivation affects employee performance indirectly through competence (Subari and Riady, 2015). Kuvaas (2006) explains the relationship between job satisfaction and employee performance is moderated by employee intrinsic motivation. The form of moderation is negative for employees with low intrinsic motivation, and positive for employees with high intrinsic motivation.

Intrinsic motivation is increasingly suspected of having a strong effect on employee performance because according to research was conducted by Finkelstein (2011), Intrinsic factor has a positive correlation with organizational citizenship behavior (OCB) as we know that OCB is a dimension of employee performance according to Organ (1988). OCB is extra-role behavior that benefits the organization. Organ (1988) saidthat this behavior is free and voluntary because this behavior is outside the formal job description. OCB is an employee with a large intrinsic motivation; she/he will have a large organizational citizenship attitude, namely cooperative and mutually helping behaviors that are outside formal requirements. However, it is very important to improve organizational performance. Based on this description, the second hypothesis can be formulated as follows: 
H2: Intrinsic motivation effect training result perception on the individual work performance of employees

\section{Extrinsic Motivation and Individual Work Performance of the Employee}

Extrinsic motivation comes from outside of employee but can help to improve individual work performance. The higher benefit that might be obtained by the employees like salary, incentives, and job promotion, the better their work performance. Extrinsic motivation play a big role in accommodating the primary needs of employees (Khan et al., 2014). Extrinsic motivation improves employees performance through good working conditions, policies, security, and relationships between employees (Emeka et al., 2015). According to Remi (2011) employees will have high motivation and work better when they feel fascinated and delighted with their work. Security, effectiveness of supervision, and trust in relationships with colleagues are important factors to improve employees performance. Shaikh et al. (2018), in their research about the effect of extrinsic motivation on employee performance in the food and textile industry in Paskistan proved that extrinsic factors have a positive and significant effect on employee performance. Another study from Parker et al. (2012), Bear et. all (2017), Chang and Teng (2017), as well as Sanjeev and Surya (2016), also prove the same thing. All extrinsic factors have a positive effect on employees performance.

Emka, et. al., (2015) stated that all extrinsic factors can increase employees motivation which then positively affect to employees performance in terms of productivity. Attrams (2013) said that extrinsic factors play as an important role in improving employees performance in both public and private companies, like monetary policy and good working relations. Meanwhile, Hong Tan and Waheed (1959) believe that extrinsic factors are more dominant than intrinsic factors in the retail industry applied in Malaysia. This study more focused on salary, company policies, and working conditions than other extrinsic factors. Rewards in the form of a salary or bonus are a primary need that must be met at every position level (Smith, 1976). According to Katz and Sinclair (2005), monetary rewards have the power to attract, retain, and motivate the employee that continue effect to high work performance.

Extrinsic motivation is strongly predicted have positive association with work performance because extrinsic factor also able to increase employee engagement in work. Khan and Iqbal's (2013) research showed that extrinsic motivation has a positive and significant relationship with employees engagement, in which it is even stronger than intrinsic factors. It confirms that the higher of extrinsic motivation, the greater of employee involvement, and vice versa. Extrinsic factors also proved have a positive correlation with employees' Organizational Citizenship Behavior (OCB) (Finkelstein, 2011). Ibrahim and Aslinda (2014) in their research toward 176 employees of Telkom Indonesia had the same results which the extrinsic factors are positively correlated with OCB, then improved the employee performance, although the level of influence is not as large as intrinsic motivation. From the those arguments, could be conclude third hypothesis as below:

H3: Extrinsic motivation effect training result perception on the individual work performance of employees

Based on the description above, it can be concluded that perceptions of training results, intrinsic and extrinsic motivation have an effect on the individual work performance of the employee. Hence, the linkage between those three variables can be described in the research model below:

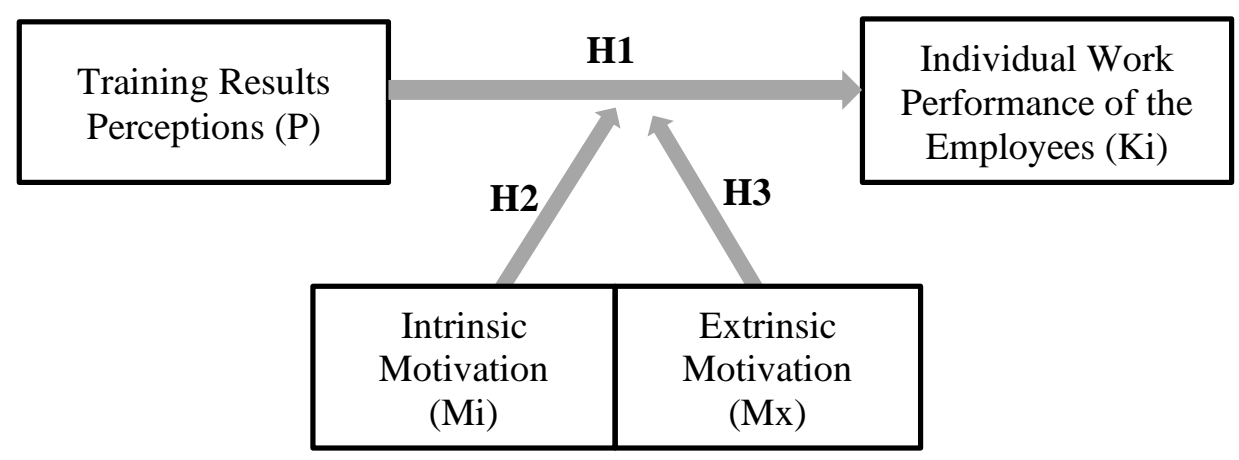

Figure 1. Research Model 


\section{RESEARCH METHODOLOGY}

\section{A. Population and Sample}

This research focused on the employees of PT KAI particularly for the field operator position who have received training in 2019 with the consideration that this groups has the largest number of positions among other positions, and they also directly related to company performance in general. From a total of 1.311 populations, 453 employees or $35 \%$ was chosen as sample by purposive random sampling technique mean that sample was chosen based on various research considerations. The samples of this research came from various locations and work units in the branch offices of PT KAI throughout Indonesia. From the results of the outlier test, there were 5 respondents indicated that they were outliers, so that only 448 samples were feasible and met the requirements for further testing. As seen from the distribution, most respondents come from the Head Office, Daop 1. Jakarta, and Balai Yasa as shown in table 1.

Table 1. Research Sample Distribution

\begin{tabular}{lcclcc}
\hline \multicolumn{1}{c}{ Work location } & Total & $\begin{array}{c}\text { Percentage } \\
(\%)\end{array}$ & \multicolumn{1}{c}{ Work location } & Total & $\begin{array}{c}\text { Percentage } \\
(\%)\end{array}$ \\
\hline Daop 1. Jakarta & 35 & $8 \%$ & Divre I. North Sumatera & 15 & $3 \%$ \\
Daop 2. Bandung & 49 & $11 \%$ & Divre II. West Sumatera & 8 & $2 \%$ \\
Daop 3. Cirebon & 17 & $4 \%$ & Divre III. Palembang & 11 & $2 \%$ \\
Daop 4. Semarang & 24 & $5 \%$ & Divre IV. Lampung & 7 & $2 \%$ \\
Daop 5. Purwokerto & 21 & $5 \%$ & Headquarters & 135 & $30 \%$ \\
Daop 6. Yogyakarta & 24 & $5 \%$ & Pusdiklat Ir. H. Djuanda & 13 & $3 \%$ \\
Daop 7. Madiun & 5 & $1 \%$ & Balai Yasa & 35 & $8 \%$ \\
Daop 8. Surabaya & 31 & $7 \%$ & LRT Division of Jabodebek & 8 & $2 \%$ \\
Daop 9. Jember & 10 & $2 \%$ & \multicolumn{1}{c}{ TOTAL } & $\mathbf{4 4 8}$ & $\mathbf{1 0 0 \%}$ \\
\hline
\end{tabular}

\section{B. Data Collection}

Data in this research were primary that were collected using a closed questionnaire consist of 89 items of questions with a Likert scale 1-5 indicating strongly disagree to strongly agree. The questionnaire for perceptual research variables used the Q4TE Training Evaluation Model of Grohmann and Kauffeld (2013); the intrinsic and extrinsic motivation variables used the Work Preference Inventory (WPI) of Amabile et al. (1994); and the individual work performance variables used the Individual Work Performance Questionnaire. (IWPQ) by Koopmans, et.al. (2013). The validity of the instrument were measured using factor analysis test and its reliability was measured using Cronbach's Alpha. Based on the factor analysis test, a total of 23 valid questionnaire items were obtained, referring to the loading value of more than 0.5 , along with valid instrument data.

Table 2. Validity Test Results with Factor Analysis

\begin{tabular}{ccccccccc}
\hline \multicolumn{2}{c}{ Training Results Perceptions } & \multicolumn{2}{c}{ Intrinsic } & \& Extrinsic Motivation & \multicolumn{3}{c}{ Individual Work Performance } \\
\hline Item & Loading Factor & Info. & Item & Loading Factor & Info. & Item & Loading Factor & Info. \\
\hline P2 & 0.678 & Valid & Mi1 & 0.628 & Valid & Ki39 & 0.776 & Valid \\
P3 & 0.779 & Valid & Mi3 & 0.615 & Valid & Ki40 & 0.792 & Valid \\
P4 & 0.821 & Valid & Mx9 & 0.764 & Valid & Ki41 & 0.726 & Valid \\
P5 & 0.845 & Valid & Mx10 & 0.780 & Valid & Ki42 & 0.796 & Valid \\
P6 & 0.844 & Valid & Mx11 & 0.619 & Valid & Ki43 & 0.509 & Valid \\
P11 & 0.761 & Valid & Mx13 & 0.775 & Valid & Ki44 & 0.828 & Valid \\
P12 & 0.733 & Valid & Mx14 & 0.696 & Valid & Ki45 & 0.825 & Valid \\
& & & & & & Ki46 & 0.833 & Valid \\
& & & & & Ki47 & 0.777 & Valid \\
\hline
\end{tabular}

All of the items above are also reliable (can be trusted). It is indicated by the alpha value of the instrument for each variable which is greater than the required value, which is 0.60 . Based on the number of Alpha value, most if them have a very high level of reliability with an average Cronbach's alpha value of 0.842 (Arikunto, 2016). 


\section{Data analysis Technique}

Hypothesis testing is carried out using Hierarchical Regression Analysis by including the Multicollinearity test as a prerequisite regression analysis. Interaction terms often create multicollinearity problems because of their correlations with main effects. We computed the interaction terms by centering the variables before multiplying them with each other. The data were analysed in two steps, first regressed each independent variable with a dependent variable without moderation and second regressed the result of multiplying each independent variable with a dependent variable to find out the moderation effect. All hypothesis results refer to significantly value (pvalue $<0,05)$.

\section{IV.RESUTS AND DISCUSSIONS}

\section{A. Multicollinearity Test}

This test aim to determine whether there is collinearity between independent variables or not as prerequisite test before the regression analysis. Below is the result of Multi-collinearity test obtained:

Table 3. Multicollinearity Test

\begin{tabular}{llrrr}
\hline & \multicolumn{2}{c}{ Model } & \multicolumn{3}{c}{ Collinearity Statistics } \\
\cline { 3 - 5 } & Perceptions of Training Results (P) & Tolerance & VIF & Conclusions \\
\hline \multirow{2}{*}{1} & Intrinsic Motivation (Mi) & 0.679 & 1.472 & \\
& Extrinsic Motivation (Mx) & 0.694 & 1.441 & No Multi-collinearity \\
& Exyyyy & 0.957 & 1.045 & \\
\hline
\end{tabular}

The table above shows that the tolerance value for all independent variables more than 0,1 and the VIF value also less than 10, so it can be identified that there is no collinearity between the three independent variables, meaning that this variable meets the requirements for regression analysis.

\section{B. Hypothesis Test}

\section{a) Training results perceptions have a positive effect to individual work performance of employees}

This hypothesis observes the direct and linear effect between training results perceptions variable $(\mathrm{P})$ on individual work performance of the employee which is described in equation model $1: \mathrm{Ki}=4,624+0,151 \mathrm{P}+\mathrm{e}$. From the analysis results, it was obtained a positive coefficient value of $0,151, \mathrm{t}$ value of 6.433 , and a significance value of $0.000(\mathrm{P}<0.05)$, meaning that the perception of training results has a positive and significant effect on individual work performance of the employee (H1 accepted).

From these results, it can also be interpreted that the higher of employee's training results perception, the higher of individual work performance. Good training will create better employees work performance. It supports the theory from Goldstein and Ford (2002) that stated if training is the systematic acquisition of new skills, rules, attitudes, and concepts in improving employee performance. Noe (2018) also prove the same thing, training is an effort is prepared by a company to facilitate the learning of its employees to acquire knowledge, skills, expertise, behavior and attitudes supporting competence in their work to achieve better performance.

In this research context, training result perception is divided into four things: reactions, learning, attitudes, and organizational results. The correlation with these findings is if these four things get good and positive perceptions from the training participants, the individual employee performance will also improve. For this reason, the company, PT KAI, hopes that it can continue to improve its training by paying attention to these four aspects. Hence, the individual performance of its employees becomes even better. It is not only the results of the training, but the learning process and the satisfaction of the trainees are also very important to note. The results of this study support several previous studies like those from Holzer (1993), Saeed and Asghar (2012), Asfaw et al. (2015) and Rakhmalina et al. (2017) which also prove that training has a positive and significant effect on employee performance. 


\section{b) Intrinsic motivation may strengthen the effect of training result perception on the individual work performance of employees}

This second hypothesis tried to involve the intrinsic and extrinsic motivation variables into the model to see their moderation on the relationship between training results perceptions and individual work performance.To find out this, it can be done by comparing the results of the analysis model 2 that included intrinsic and extrinsic motivation variables, with model 3 (full model) that has involved all the independent variables and their interactions. Following are the results of the partial analysis $t$ test for the involvement of intrinsic motivation variable in each model:

Table 4. Results of the Significance Analysis of the t-test Before and After Moderation by Intrinsic Motivation Variables (Mi)

\begin{tabular}{|c|c|c|c|c|c|c|c|c|}
\hline \multirow{2}{*}{ Variable } & \multicolumn{4}{|c|}{$\begin{array}{l}\text { Model } 2^{\mathrm{b}} . \text { Before Moderation } \\
\mathrm{R}^{2}=0,112 \text {, Constant }=4,625\end{array}$} & \multicolumn{4}{|c|}{$\begin{array}{l}\text { Model } 3^{\mathrm{c}} \text {. After Moderation } \\
\mathrm{R}^{2}=0,113 \text {, Constant }=4,620\end{array}$} \\
\hline & $\begin{array}{l}\text { Koef } \\
\text { (B) }\end{array}$ & $\mathrm{t}$ value & Sig. & Info. & $\begin{array}{l}\text { Koef } \\
\text { (B) }\end{array}$ & $\mathrm{t}$ value & Sig. & Info. \\
\hline $\mathrm{P} \rightarrow \mathrm{Ki}$ & 0.116 & 4.126 & 0.000 & Significant & 0.119 & 4.045 & 0.000 & Significant \\
\hline $\mathrm{Mi} \rightarrow \mathrm{Ki}$ & 0.033 & 1.200 & 0.231 & Not Significance & 0.032 & 1.131 & 0.259 & Not Significance \\
\hline $\mathrm{Mi} * \mathrm{P} \rightarrow \mathrm{Ki}$ & & & & & 0.014 & 0.552 & 0.581 & Not Significance \\
\hline \multicolumn{9}{|c|}{$\begin{array}{l}\text { a. Dependent Variable: Performance (Ki) } \\
\text { b. Model 2, Predictors: (Constant), Extrinsic Motivation (Mx), Intrinsic Motivation (Mi), Training (P) } \\
\text { c. Model 3, Predictors: (Constant), Training (P), Extrinsic Motivation (Mx), Intrinsic Motivation (Mi), } \\
\text { Training *Intrinsic Motivation, Training *Extrinsic Motivation }\end{array}$} \\
\hline
\end{tabular}

From the results above, the regression equation of intrinsic motivation as moderation is obtained follows:

$$
K i=4.620+0.119 P+0.032 M i * P+e
$$

These results indicate that training consistently has a positive and significant effect on individual work performance of employees was proven by a significance value of $0.000(\mathrm{P} \rightarrow \mathrm{Ki})$ and a positive coefficient value of 0.116 , both before and after moderation, the results were equally significant $\mathrm{P}=0.000(\mathrm{P}<0.05)$. Likewise with the intrinsic motivation variable, after and before moderating, it partially have no significant effect to individual work performance of the employee (Mi $\rightarrow \mathrm{Ki}$ ). It is evident from the significance value that always more than $0.05(\mathrm{P}=0.231)$ in model 2 and $(\mathrm{P}=0.581)$ in model 3. Related to the research hypothesis, it can be seen that intrinsic motivation does not moderate the relationship between the training results perception and individual work performance of the employee. This is indicated by the significance value between the interaction of intrinsic motivation and training to work performance $(\mathrm{Mi} * \mathrm{P} \rightarrow \mathrm{Ki})$ which is more than $0.05(\mathrm{P}=0.581)$. Hence, the hypothesis can be concluded that intrinsic motivation, does not moderate or strengthen the effect of training results perception to individual work performance of the employee. Seeing from the value of $\mathrm{R}^{2}$ there is no significant change, it only increases by 0.01 , from $\mathrm{R}^{2}=0.112$ to $\mathrm{R}^{2}=0.113$.

Intrinsic motivation in this study refers to Work Preference Inventory (WPI) developed by Amabile et al. (1994). There are five dimensions of motivation measured: personal decisions (prefer choice or autonomy), competence (mastery orientation and prefer challenges), involvement in work (completion and task flow), curiosity, and interest in work (pleasure and enjoyment of work). In fact, the research results show that the good and bad performance of PT KAI employees, especially in the field operator positions group, has no relation with their intrinsic motivation. Workers with good performance may be affected by other outside individual factors. According to Vroom (1964), intrinsic and extrinsic motivation applies to certain types of employees, there are employees who are very concerned with intrinsic results, and there are also those who are concerned with extrinsic results, or can even be motivated by both intrinsic and extrinsic. Moreover, in this case, PT KAI employees are kind of employees who are not concerned with intrinsic results.

This study contrast with research by Lin (2011), Lepper et al. (1999), Amabile, (1996), Okilo (2003), Kuvaas (2006), and Finkelstein (2011) which has proven that intrinsic motivation has a positive association with employee performance. It is understandable, because basically there are many predictors of work performance, not only from intrinsic but also extrinsic factors. Organizational culture, type of company, work environment, can also be determinants of work performance. As well as Simanjuntak (2005), Each person's performance is affected by 
many factors which can be classified into three groups: the individual competence of the person concerned, organizational support, and management support.

\section{c) Extrinsic motivation may strengthen the effect of training result perception on the individual work} performance of employees

Similar with intrinsic motivation, this hypothesis testing is also carried out by comparing the results of the $t$ test model 2 and model 3 as in table 5 .

Table 5. Results of the Significance Analysis of the t-test Before and After Moderation by Extrinsic Motivation Variables (Mx)

\begin{tabular}{|c|c|c|c|c|c|c|c|c|}
\hline \multirow{2}{*}{ Variable } & \multicolumn{4}{|c|}{$\begin{array}{l}\text { Model } 2^{\mathrm{b}} . \text { Before Moderation } \\
\mathrm{R}^{2}=0,112, \text { Constant }=4,625\end{array}$} & \multicolumn{4}{|c|}{$\begin{array}{l}\text { Model } 3^{\mathrm{c}} \text {. After Moderation } \\
\mathrm{R}^{2}=0,113 \text {, Constant }=4,620\end{array}$} \\
\hline & $\begin{array}{l}\text { Koef } \\
\text { (B) }\end{array}$ & t value & Sig. & Info. & $\begin{array}{l}\text { Koef } \\
\text { (B) }\end{array}$ & $\mathrm{t}$ value & Sig. & Info. \\
\hline $\mathrm{P} \rightarrow \mathrm{Ki}$ & 0.116 & 4.126 & 0.000 & Significant & 0.119 & 4.045 & 0.000 & Significant \\
\hline $\mathrm{Mx} \rightarrow \mathrm{Ki}$ & 0.081 & 3.418 & 0.001 & Significant & 0.085 & 3.354 & 0.001 & Significant \\
\hline $\mathrm{Mx} * \mathrm{P} \rightarrow \mathrm{Ki}$ & & & & & -0.012 & -0.438 & 0.662 & Not Significance \\
\hline \multicolumn{9}{|c|}{$\begin{array}{l}\text { a. Dependent Variable: Performance }(\text { Ki) } \\
\text { b. Model 2, Predictors: (Constant), Extrinsic Motivation (Mx), Intrinsic Motivation (Mi), Training (P) } \\
\text { c. Model 3, Predictors: (Constant), Training (P), Extrinsic Motivation (Mx), Intrinsic Motivation (Mi), } \\
\text { Training *Intrinsic Motivation, Training *Extrinsic Motivation }\end{array}$} \\
\hline
\end{tabular}

From analysis results, the regression equation of extrinsic motivation as moderation is obtained as follows:

$$
K i=4.620+0.11 P+0.085 M x-0.012 M x * P+e
$$

In contrast to intrinsic motivation, extrinsic motivation partially has a positive and significant effect on individual work performance of the employee $(\mathrm{Mx} \rightarrow \mathrm{Ki})$. Both model 2 and model 3 obtained significant results with a $\mathrm{P}$ value $=0.001(\mathrm{P}<0.05)$ and a positive coefficient value of 0.081 and 0.085 . The interesting thing about this finding is that although it has a significant effect, this extrinsic motivation does not moderate the relationship between training result perceptions and individual work performance. It can be seen from the significance value of the interaction variable $(\mathrm{Mx} * \mathrm{P} \rightarrow \mathrm{Ki})$ which is greater than $0.05, \mathrm{P}=0.662$. Even if viewed from the coefficient value, a negative value of -0.012 is obtained, far from the proposed hypothesis. It means that extrinsic motivation does not strengthen the relationship between perceptions of training results and individual work performance of the employee (H3 rejected).

Training results perceptions and extrinsic motivation simultaneously have a positive and significant impact on individual work performance of the employee. From the follow-up test by only involved the training results perception and extrinsic motivation variable, the significance value was obtained less than 0.005 as shown in table 6.

Table 6. Simultaneous Test Results (F-Test) on Perceptions of Training Results and Extrinsic Motivation

\begin{tabular}{|c|c|c|c|c|c|c|}
\hline Model & & Sum of Squares & df & Mean Square & $\mathrm{F}$ & Sig. \\
\hline \multirow{3}{*}{1} & Regression & 13,084 & 2 & 6,542 & 27,216 & $.000^{\mathrm{b}}$ \\
\hline & Residual & 106,965 & 445 & .240 & & \\
\hline & Total & 120,049 & 447 & & & \\
\hline
\end{tabular}

There is no collinearity relationship between the two variables, meaning that both of them are independent, do not influence each other or even moderate. Training results perceptions and extrinsic motivation both are able to improve the individual performance of PT KAI employees. It can be assumed that even though the training is not extremely good, if PT KAI provides more support on the external motivation aspect, then employee performance can still increase, and vice versa. It is an option for PT KAI regarding how the organization will improve the performance of its employees, whether want to focus more on training, or external motivation alone, or even through both. It depends on the vision and resources of PT KAI itself. With regard to Vroom's (1964) opinion, it 
can be identified that PT KAI employees especially for the field operator positions are more oriented towards extrinsic results than intrinsic ones. A field operator employee is identified as an employee who occupies the lowest position in PT KAI's organizational structure that implemented day to day basis task on the ground and implemented all task assigned by directors or executive position.

From these results, it can be interpreted that compared to intrinsic motivation, extrinsic motivation contributes more to individual work performance of the employee. Extrinsic motivation in this study was assessed from employees' concern for evaluation, recognition/rewards, competition/competition, money/incentives and orders from others. In line with the research of Khan et al. (2014), Lin (2011), Saeed and Asghar (2012), Remi (2011), Parker et al. (2012), Bear et. al. (2017), Chang and Teng (2017), and Sanjeev and Surya (2016) that have proven that extrinsic motivation has a positive and significant effect on employee performance in both public and private companies (Shaikh et al., 2018). Attrams (2013) states that extrinsic factors serve a major role in improving employee performance in both public and private companies like monetary policy and good working relations. Meanwhile, Hong Tan and Waheed (1959) believe that extrinsic factors are more dominant than intrinsic factors in the retail industry applied in Malaysia. This study focuses more on salary, company policies, and working conditions than other extrinsic factors. Rewards in the form of a salary or bonus are a primary need that must be met at every level of position (Smith, 1976). According to Katz and Sinclair (2005), monetary rewards have the power to attract, retain, and motivate the employee in which in its turn, it has an effect on high performance.

\section{CONCLUSIONS AND IMPLICATIONS}

The training result perceptions and extrinsic motivation simultaneously or partially have a positive and significant effect on individual work performance of employee, but intrinsic motivation have no effect to work performance. Intrinsic or extrinsic motivation does not moderate or strengthen the relationship between training result perceptions and individual work performance of employee. Those three independent variables are independent and not related to each other. The first hypothesis (H1) is accepted, while $\mathrm{H} 2$ and $\mathrm{H} 3$ are rejected or not proven.

The employees of PT KAI, especially those in the field operator positions, are more oriented towards extrinsic results than intrinsic ones. The implication for PT KAI is that if they want to improve the individual work performance of its employees, PT KAI may focus on improving training, external motivation or both. This depends on the vision, long-term goals, and resources of PT KAI itself. Considering that the perception of training results is proven to be a predictor of employee work performance, it is recommended that PT KAI continues developing effective training strategies and provides satisfaction to training participants. Regarding external motivation, PT KAI should direct more pays attention to aspects like employee welfare, work environment, work culture, including aspects of evaluation and appreciation for employees that will be able to foster positive performance and hopefully the overall organizational performance will be better.

\section{REFERENCES}

Aamodt MG. 2015. Industrial/Organizational Psychology an Applied Approach. Eight Edition. Cengage Learning. Boston

Ahmad K \& Bakar RA. 2003. The association between training and organizational commitment among whitecollar workers in Malaysia. International Journal of Training and Development, Vol. 7 No. 3, p. 166-185.

Amabile J., Cantor P \& Sparks RW. (2003). Efficiency wages and the regulated firm. Journal of Regulatory Economics, 11, p.55-66.

Amabile Teresa M, Hill Karl G., Hennessey Beth A., dan Tighe Elizabeth M. 1994. The Work Preference Inventory: Assessing Intrinsic and Extrinsic Motivational Orientations. Journal of Personality and Social Psychology. Vol. 66, No. 5, 950-967

Asfaw AM., Argaw MD \& Bayissa L. 2015. The Impact of Training and Development on Employee Performance and Effectiveness: A Case Study of District Five Administration Office, Bole Sub-City, Addis Ababa, Ethiopia, Journal of Human Resource and Sustainability Studies, 3(1), p.188-202

Axtell C \& Parker SK. 2003. Promoting Role Breadth Self-Efficacy Through Involvement, Work Redesign and Training. Article Human Relation. Sage Publications. Australia. pp113 
Bakker A. 2017. Strategic and proactive approaches to work engagement. Organizational Dynamics, Vol. 46 No. 2, p. 67-75.

Baron RM \& Kenny DA. 1986. The Moderasi-Mediator Variable Distinction in Social Psychological Research: Conceptual, Strategic, and Statistical Considerations. Journal of Pesonality and Social Psychology, 51(6), p. 1173-1182.

Booth AL. 1991. Job-Related Formal Training: Who Receives it and What is it Worth? Journal Oxford Bulletin of Economics and Statistics Vol. 53 No. 3 p. 281-294

Bukit B, Malusa R, dan Rahmat A. 2017. Pengembangan Sumber Daya Manusia. Zahir Publishing. Yogyakarta

Chiang C., Back KJ \& Canter DD. (2005), "The impact of employee training on job satisfaction and intention to stay in the hotel industry. Journal of Human Resources in Hospitality \& Tourism, Vol. 4 No. 2, p. 99-118.

Colquitt JA, Lepine J, \& Wesso M. 2019. Organizational Behaviour Improving Performance and Commitment in Workplace Sixth Edition. McGraw-Hill Education. New York

Csikszentmihalyi A. 1975. Intrinsic and Extrinsic Motivational Orientations in the Competitive Context: An Examination of Person-Situation Interactions. University of Chicago, Claremont Graduate University.

Dysvik A \& Kuvaas B. 2013. Intrinsic and extrinsic motivation as predictors of work effort: The moderating role of achievement goals. British Journal of Social Psychology. 52, p. 412-430

Earley PC. 1994. Self or group? Cultural effects of training on self-efficacy and performance. Journal Administrative Science Quarterly, Vol. 39 No.1, p. 89-117.

Elnaga A. and Imran A. 2013. The effect of training on employee performance. International Journal of Business and Management, Vol. 5 No. 4, p. 137-147.

Emeka N., Amaka O \& Ejim EP. 2015. The Effect of employee motivation on organizational performance on selected manufacturing firm in enugu state. Journal of Personality and Social Psychology, 3(1), p. 1-8

Finkelstein MA. 2011. Intrinsic and extrinsic motivation and organizational citizenship behavior: A functional approach to organizational citizenship behavior. Journal of Psycological Issues in Organizational Culture 2. P. $19-34$

Firmandani. 2014. Pengaruh Kompensasi terhadap Kinerja Karyawan dengan Motivasi sebagai Variabel Moderasi pada Bank Syariah Mandiri Kantor Cabang Yogyakarta. Jurnal Ekonomi dan Bisnis. Vol. IX, No. 1

Fletcher L. 2016. Training perceptions, engagement, and performance: comparing work engagement and personal role engagement. Human Resource Development International, Vol. 19 No. 1, p. 4-26.

Fletcher L., Alfes K \& Robinson D. 2016. The relationship between perceived training and development and employee retention: the mediating role of work attitudes. The International Journal of Human Resource Management, p. 1-28.

Grohmann A \& Kauffeld S. 2013. Evaluating training programs: development and correlates of the Questionnaire for Professional Training Evaluation. International Journal of Training and Development 17:2 ISSN 13603736. Blackwell Publishing Ltd

Guan X \& Frenkel S. 2018. How perceptions of training impact employee performance Evidence from two Chinese manufacturing firms. Personnel Review, Vol. 48 Issue: 1, pp.163-183

Holzer HJ., Block RN., Cheatham M \& Knott JH. 1993. Are Training Subsidies for Firms Effective? The Michigan Experience. Industrial and Labour Relations Review Vol. 46 p. 625-636.

Hong Tan T., Waheed B \& Snyderman BS. 1959. Herberg's motivation theory and job satisfaction in the Malaysian retail sector. The mediating effect of love of money. Asean academy of management journa, 16 (1), p. 73-94

Lin. 2011. The effects of employee motivation, social interaction, and knowledge management strategy on KM implementation level. Knowledge Management Research \& Practice (2011) 9, 263-275. Department of Shipping and Transportation Management, National Taiwan Ocean University. Taiwan

Ibahim MA \& Aslinda. 2014. The Effect of Motivation on Organizational Citizenship Behaviour (OCB) at Telkom Indonesia in Makassar. International Journal of Administrative Science \& Irganization. Vol 21 No. 2. p. 115 
Khan W \& Iqbal Y. 2013. An investigation of the relationship between work motivation (intrinsic \& extrinsic) and employee engagement a study on allied bank of pakistan. Master Thesis. Umeå School of Business Umeå University

Khan, A., Latif, F., Jalal, W., Anjum, R., \& Rizwan, M. (2014). The Impact of Rewards \& Corporate Social Responsibility (CSR) On Employee Motivation.International. Journal of Human Resource Studies, 4(3). p.70.

Koopmans L., Bernaards CM., Hildebrandt VH., Coffeng JK \& Boot CRL. 2013. Development of an individual work performance questionnaire. International Journal of Productivity and Performance Management, Vol. 62 Iss: 1 p. $6-28$.

Kuvaas B. 2006. Performance appraisal satisfaction and employee outcomes: mediating and moderating roles of work motivation. The International Journal of Human Resource Management ISSN 0958-5192 print/ISSN 1466-4399

Lepper MR., Hendelong J \& Gingras L. 1999. Understanding the Effect of Extrinsic Reward on Intrinsic Motivation - Uses Abuses of Metaanalysis: Comment on Deci, Koestner, \& Ryan. Psychological Bulletin, 125. p.669-676

Luthans F. 2011. Organisasi Behavior, Eighth Edition. McGraw-Hill Intemasional Book Company. New York.

Lynch L. 1992. Private-Sector Training and the Earnings of Young Workers. American Economic Review, Vol. 82 No. 1, p. 299-312.jawa

Priyono \& Marnis. 2008. Manajemen Sumber Daya Manusia. Zifatama Publisher. Sidoarjo

Rakhmalina I., Emelda E., Hafid H \& Periansya P. 2017. Influence of Motivation and Job Training (The Performance of Employees PT. RB Sukasada Palembang). Jurnal Terapan Manajemen dan Bisnis Vol 3, 2 Oktober 2017. Page 147-153.e-ISSN: 2477-5282

Remi JA. 2011. An empirical study of the motivational factors of employee in Nigeria. International journal of economic and finance 55 (1). p. 68-78

Ryan M.R, (2000). Intrinsic and extrinsic Motivations: Classic definitions and new direction. Journal of Psychology, 25, 54-67.

Saeed MM \& Asghar MA. 2012. Examining the Relationship between Training, Motivation and Employees Job Performance - The Moderating Role of Person Job Fit 2012. Journal of Basic and Applied Scientific Research ISSN 2090-4304

Salanova M., Agut S \& Peiró, JM. 2005. Linking organizational resources and work engagement to employee performance and customer loyalty: the mediation of service climate. Journal of Applied Psychology, Vol. 90 No. 6, p. 1217-1227.

Sanjeev MA \& Surya AV. 2016. Two factor theory of motivation and satisfaction: an empirical verivication. Annals of data science. p. 1-83

Simbula S., Guglielmi D., \& Schaufeli WB. 2011. A three-wave study of job resources, self-efficacy, and work engagement among Italian schoolteachers. European Journal of Work and Organizational Psychology, Vol. 20 No. 3, p. 285-304.

Subari S \& Raidy H. 2015. Influence of Training, Competence and Motivation on Employee Performance, Moderated by Internal Communications. American Journal of Business and Management. Vol. 4, No. 3, p:133-145

Toufaili BEL. 2018. The Impact of Intrinsic and Extrinsic Motivation on Job Satisfaction among Employees: A Theoretical Approach. Account and Financial Management Journal e-ISSN: 2456-3374. Volume 3 Issue 10 October- 2018, (Page No.-1746-1748). Lebanese International University LIU

Vroom V. 1964. Work and Motivation. John Willey \& Sons. New York

Wright PM \& Kehoe RR. 2007. "Human Resource Practices and Organizational commitment: A Deeper Examination." Asia Pacific Journal of Human Resources 46(1), p. 6 